\title{
BATU BARA SEBAGAI ADSORBEN
}

\author{
Riang Adeko, Agus Widada \\ Politeknik Kesehatan Kementerian Kesehatan Bengkulu, Jurusan Kesehatan Lingkungan, \\ Jalan Indragiri Nomor 3 Padang Harapan Bengkulu \\ keslingbkl@yahoo.com
}

\begin{abstract}
Providing clean water to the community has a very important role in improving the environment or public health, which has a role in reducing the number of people with the disease, especially those related to water, and its role in improving the standard or level / quality of life. initial survey conducted on February 20, 2016 in RW. 03 Village Rawa Makmur Permai Bengkulu City after measurements were obtained Iron (Fe) $0.9 \mathrm{mg} / \mathrm{L}$; Manganese $(\mathrm{Mn})$ of $0.87 \mathrm{mg} / \mathrm{L}$. From the measurement results in the initial survey is known that water wells RW.03 village residents Rawa Makmur Permai Bengkulu city still exceeds the threshold required by Permenkes RI 416 / Menkes / per / IX / 1990. The purpose of this study was to determine the reduced levels of $\mathrm{Fe}$ and $\mathrm{Mn}$ before and after treatment by using a variation of coal thickness of $20 \mathrm{~cm}, 30 \mathrm{~cm}$ and 50 $\mathrm{cm}$ as well as to the most effective menegetahui thickness variation to reduce levels of Fe and Mn. This research uses experimental methods pure (True Experimental) experimental design with Pre-Post test, the research conducted before and after treatment. Then look for the difference between the measurement of both, and the difference is considered as a result of treatment. Results of the study is the reduction of Fe content using coal decreased by $42 \%$ and decreased levels of Mn using coal decreased by $35 \%$. The result showed that the thicker the more effective adsorbent decline.
\end{abstract}

Keywords: Adsorbent, Coal, Well Drilling

\begin{abstract}
Abstrak : Penyediaan air bersih untuk masyarakat mempunyai peranan yang sangat penting dalam meningkatkan kesehatan lingkungan atau masyarakat, yakni mempunyai peranan dalam menurunkan angka penderita penyakit, khususnya yang berhubungan dengan air, dan berperan dalam meningkatkan standar atau taraf/kualitas hidup masyarakat. Survei awal yang dilakukan pada tanggal 20 Februari 2016 di sumur gali warga RW. 03 Kelurahan Rawa Makmur Permai Kota Bengkulu setelah dilakukan pengukuran diperoleh Besi (Fe) 0,9 mg/L; Mangan (Mn) 0,87 mg/L. Dari hasil pengukuran pada survey awal diketahui bahwa air sumur gali warga RW.03 Kelurahan Rawa Makmur Permai Kota Bengkulu masih melebihi ambang batas yang dipersyaratkan oleh Permenkes RI No.416/Menkes/per/IX/1990. Tujuan penelitian ini adalah untuk mengetahui penurunan kadar $\mathrm{Fe}$ dan $\mathrm{Mn}$ sebelum dan sesudah perlakuan dengan menggunakan variasi ketebalan batubara $20 \mathrm{~cm}, 30 \mathrm{~cm}$, dan $50 \mathrm{~cm}$ serta untuk menegetahui variasi ketebalan paling efektif untuk menurunkan kadar Fe dan Mn. Jenis penelitian ini menggunakan metode eksperimen murni (True Experimental) dengan desain eksperimen Pre-Post test, yaitu penelitian dilakukan sebelum dan sesudah perlakuan. Kemudian dicari perbedaan antara pengukuran dari keduanya, dan perbedaan ini dianggap sebagai akibat perlakuan. Hasil penelitian adalah penurunan kadar $\mathrm{Fe}$ menggunakan batu bara terjadi penurunan sebesar $42 \%$ dan juga penurunan kadar $\mathrm{Mn}$ menggunakan batu bara terjadi penurunan sebesar 35\%. Hasil penelitian diperoleh bahwa semakin tebal adsorben maka semakin efektif penurunannya.
\end{abstract}

Kata Kunci : Adsorben, Batu Bara, Sumur Gali

Penyediaan air bersih untuk masyarakat mempunyai peranan yang sangat penting dalam meningkatkan kesehatan lingkungan atau masyarakat, yakni mempunyai peranan dalam menurunkan angka penderita penyakit, 
khususnya yang berhubungan dengan air, dan berperan dalam meningkatkan standar atau taraf/kualitas hidup masyarakat. Berdasarkan survei awal yang dilakukan pada tanggal 20 Februari 2016 di sumur gali warga RW. 03 Kelurahan Rawa Makmur Permai Kota Bengkulu setelah dilakukan pengukuran diperoleh Besi $(\mathrm{Fe})$ 0,9 mg/L; Mangan (Mn) 0,87 mg/L. Hasil pengukuran pada survei awal diketahui bahwa air sumur gali warga RW.03 Kelurahan Rawa Makmur Permai Kota Bengkulu masih melebihi ambang batas yang dipersyaratkan oleh Permenkes RI No.416/ Menkes/ per/ IX/ 1990.

Mengatasi masalah tersebut, perlu dilakukan proses penjernihan air dengan membuat suatu alat penjernihan dengan media yang mudah di peroleh dipasaran yaitu karbon aktif. Karbon aktif dipilih karena mampu dalam proses penyerapan zat organik maupun anorganik, sebagai penukar kation dan katalis untuk berbagai reaksi. Bahan baku yang akan dikembangkan sebagai karbon aktif adalah limbah batu bara. Limbah batu bara merupakan hasil buangan proses pengolahan pada industri batu bara sehingga berdampak pada pencermaran lingkungan.

\section{BAHAN DAN CARA KERJA}

Jenis penelitian yang digunakan adalah eksperimen murni (True Experimental) dengan desain eksperimen Pre-Post test, yaitu penelitian dilakukan sebelum dan sesudah perlakuan. Kemudian dicari perbedaan antara pengukuran dari keduanya, dan perbedaan ini dianggap sebagai akibat perlakuan. Lokasi penelitian pada sumur gali dikawasan RW.03 Kelurahan Rawa Makmur Permai dengan alokasi waktu penelitian selama 2 bulan.

\section{HASIL}

\section{Analisis Univariat}

Analisa univariat bertujuan mendeskripsikan hasil pengukuran kadar Fe dan Mn dalam bentuk tabel distribusi sebagai berikut:

Tabel 1. Rata-rata Kadar Fe Air Bersih Rawa Makmur Permai

\begin{tabular}{|c|c|c|c|c|}
\hline \multirow[b]{2}{*}{ Perlakuan } & \multirow[t]{2}{*}{ Ketebalan } & \multicolumn{2}{|c|}{ Kadar Fe (mg/l) } & \multirow[b]{2}{*}{ \% Penurunan } \\
\hline & & Sebelum & Sesudah & \\
\hline \multirow{3}{*}{ Batu bara } & $20 \mathrm{~cm}$ & 0,9 & 0,81 & 10 \\
\hline & $30 \mathrm{~cm}$ & 0,9 & 0,60 & 33.33 \\
\hline & $50 \mathrm{~cm}$ & 0,9 & 0,48 & 46,67 \\
\hline
\end{tabular}

Berdasarkan tabel 1. masing-masing kadar Fe sebelum perlakuan adalah 0,9 $\mathrm{mg} / \mathrm{l}$, jadi dari 3 perlakuan tersebut yang paling tertinggi penurunannya adalah terletak pada perlakuan ketebalan batu bara $50 \mathrm{~cm}$ dengan presentase penurunan $46,67 \%$.

Tabel 2. Rata-rata Kadar Mn Air Bersih Rawa Makmur Permai

\begin{tabular}{ccccc}
\hline Perlakuan & Ketebalan & \multicolumn{2}{c}{ Kadar Mn (mg/l) } & \\
& & Sebelum & Sesudah & \% Penurunan \\
\hline Batu bara & $20 \mathrm{~cm}$ & 0,87 & 0,78 & 10,34 \\
& $30 \mathrm{~cm}$ & 0,87 & 0,69 & 20,69 \\
& $50 \mathrm{~cm}$ & 0,87 & 0,52 & 40,23 \\
\hline
\end{tabular}

Berdasarkan tabel 2. masing-masing kadar Mn sebelum perlakuan adalah 0,87 $\mathrm{mg} / \mathrm{l}$, jadi dari 3 perlakuan tersebut yang paling tertinggi penurunannya adalah terletak pada perlakuan ketebalan batu bara 
$50 \mathrm{~cm}$ dengan presentase penurunan 40,23 $\%$.

\section{Analisis Bivariat}

Analisis bivariat digunakan untuk mengetahui perbedaan tingkat penurunan kadar $\mathrm{Fe}$ dan $\mathrm{Mn}$ pada masing-masing perlakuan dengan menggunakan uji statistik Kruskall Wallis. Hasil uji Kruskall Wallis untuk mengetahui perbedaan pada masing-masing perlakuan dapat dilihat pada tabel berikut :

Tabel 3. Hasil uji Kruskall Wallis Perbedaan Tingkat Penurunan Kadar Fe

\begin{tabular}{llcc}
\hline \multicolumn{2}{c}{ Perlakuan } & $\begin{array}{c}\text { Rata-rata } \\
\text { perbedaan }\end{array}$ & $\begin{array}{c}\boldsymbol{p} \\
\text { value }\end{array}$ \\
\hline \multirow{3}{*}{ Pre test } & Perlakuan $20 \mathrm{~cm}$ & 14,5 & 0,002 \\
& Perlakuan $30 \mathrm{~cm}$ & 10,5 & 0,002 \\
Perlakuan & Perlakuan $50 \mathrm{~cm}$ & 6,5 & 0,002 \\
$20 \mathrm{~cm}$ & Perlakuan $30 \mathrm{~cm}$ & 6,5 & 0,020 \\
& & 2,5 & 0,020 \\
Perlakuan & Perlakuan $50 \mathrm{~cm}$ & 2,5 & 0,020 \\
$30 \mathrm{~cm}$ & Perlakuan $50 \mathrm{~cm}$ & 2,5 \\
\hline
\end{tabular}

Tabel 3. diketahui hasil perbedaan mean (mean difference) antara sebelum perlakuan dengan hasil menggunakan perlakuan menunjukkan kadar Fe sebelum perlakuan dengan perlakuan ketebalan batu bara $50 \mathrm{~cm}$ adalah paling besar perbedaan mean (mean difference) yakni 6,5 dengan demikian yang paling efektif adalah perlakuan dengan ketebalan batu bara 50 $\mathrm{cm}$.

Tabel 4. Hasil Uji Kruskall Wallis Perbedaan Tingkat Penurunan Kadar Mn

\begin{tabular}{llcc}
\hline \multicolumn{2}{c}{ Perlakuan } & $\begin{array}{c}\text { Rata-rata } \\
\text { perbedaan }\end{array}$ & $\begin{array}{c}\text { p } \\
\text { value }\end{array}$ \\
\hline \multirow{3}{*}{ Pre test } & Perlakuan $20 \mathrm{~cm}$ & 14,5 & 0,002 \\
& Perlakuan $30 \mathrm{~cm}$ & 10,5 & 0,002 \\
Perlakuan & Perlakuan $50 \mathrm{~cm}$ & 6,5 & 0,002 \\
$20 \mathrm{~cm}$ & Perlakuan $30 \mathrm{~cm}$ & 6,5 & 0,020 \\
& & 2,5 & 0,020 \\
Perlakuan & Perlakuan $50 \mathrm{~cm}$ & 2,5 & 0,021 \\
$30 \mathrm{~cm}$ & Perlakuan $50 \mathrm{~cm}$ & 2 & \\
\hline
\end{tabular}

Tabel 4. diketahui hasil perbedaan mean (mean difference) antara sebelum perlakuan dengan hasil menggunakan perlakuan menunjukkan hasil kadar $\mathrm{Mn}$ sebelum perlakuan dengan perlakuan ketebalan batu bara $50 \mathrm{~cm}$ adalah paling besar perbedaan mean (mean difference) yakni 6,5 dengan demikian yang paling efektif adalah perlakuan dengan ketebalan batu bara $50 \mathrm{~cm}$.

\section{PEMBAHASAN}

Berdasarkan hasil uji Kruskall Wallis diketahui bahwa masing-masing perlakuan dengan menggunakan variasi ketebalan batu bara terhadap penurunan kadar Fe dan Mn memiliki penurunan yang berbeda beda, dengan hasil uji yang didapat $p=0,002$. Hasil analisis univariat menunjukkan bahwa perlakuan ketiga memiliki tingkatan penurunan yang paling efektif. Semakin tebal batu bara yang digunakan maka semakin efektif dalam menurunkan kadar Fe dan Mn. Berikut ini hasil uji laboratorium dimaksud.

\section{Penurunan Kadar Fe dengan Variasi Ketebalan Batu Bara}

Berdasarkan hasil analisis diperoleh bahwa kandungan $\mathrm{Fe}$ pada penyaringan dengan menggunakan batu bara pemeriksaaan pre test adalah $0,900 \mathrm{mg} / \mathrm{l}$. Hasil atau terjadi penurunan sekitar 46,67 $\%$. Hasil ini menunjukkan bahwa batu bara berpengaruh terhadap penurunan kadar $\mathrm{Fe}$ dalam air. Batu bara merupakan batuan sedimen yang secara kimia dan fisika adalah heterogen dan mengandung unsurunsur karbon, hidrogen dan oksigen sebagai unsur utama dan belerang serta nitrogen sebagai unsur tambahan. Zat lain, yaitu senyawa organik pembentuk "ash" tersebar sebagai partikel zat mineral dan terpisah-pisah di seluruh senyawa batubara.

\section{Penurunan Kadar Mn dengan Variasi Ketebalan Batu Bara}

Berdasarkan hasil analisis diperoleh bahwa kandungan Mn pada penyaringan dengan menggunakan batu bara pemeriksaaan pre test adalah $0,8700 \mathrm{mg} / \mathrm{l}$. Hasil atau terjadi penurunan sekitar 40,23 
\%. Hasil ini menunjukkan bahwa batu bara berpengaruh terhadap penurunan kadar Mn dalam air. Batu bara merupakan batuan sedimen yang secara kimia dan fisika adalah heterogen dan mengandung unsurunsur karbon, hidrogen dan oksigen sebagai unsur utama dan belerang serta nitrogen sebagai unsur tambahan. Zat lain, yaitu senyawa organik pembentuk "ash" tersebar sebagai partikel zat mineral dan terpisah-pisah di seluruh senyawa batubara.

Berdasarkan hasil pengujian secara keseluruhan dengan menggunakan variasi ketebalan batubara $20 \mathrm{~cm}, 30 \mathrm{~cm}, 50 \mathrm{~cm}$, diketahui bahwa air sumur gali warga RW.03 Kelurahan Rawa Makmur Permai

\section{DAFTAR PUSTAKA}

Arifin. 2007. Tinjauan dan Evaluasi Proses Kimia (Koagulasi, Netralisasi, Desinfeksi) Instalasi Pengolahan Air Minum Cikokol, Tangerang. Tangerang : PT.Tirta Kencana Cahaya Mandiri.

Depkes RI. 2010. Peraturan Mentri Kesehatan Republik Indonesia Nomor 492/Menkes/Per/IV/2010 Tentang Persyaratan Kualitas Air Minum. Jakarta

Depkes RI. 2005. Peraturan Mentri Kesehatan Republik Indonesia Nomor
Kota Bengkulu telah sesuai dengan persyaratkan oleh Permenkes RI No.416/Menkes/per/IX/1990.

\section{KESIMPULAN}

Hasil penelitian yang telah dilakukan, dapat diambil simpulan bahwa media batu bara dengan ketebalan $50 \mathrm{~cm}$ dapat menurunkan kadar Fe hingga 46,67 \% dan dapat menurunkan kadar Mn hingga 40,23 $\%$. Penelitian ini dapat diterapkan untuk mengolah limbah cair kimia laboratorium, dan dapat digunakan sebagai bahan pembelajaran pada mata kuliah PAPLC (pengolahan air dan pengolahan limbah cair).
Persyaratan Kualitas Air Minum. Jakarta

Daud dan Rosman, 2002, Penyediaan air Bersih, Jurusan Kesehatan Lingkungan FKM Unhas Makasar.

Said, N I. 2003. Metoda Praktis Penghilangan Zat Besi dan Mangan Di Dalam Air Minum. Jakarta : Kelair - BPPT

Sutrisno, C.T.2006. Teknologi Penyediaan Air Bersih. Jakarta. Rineka Cipta. 